\title{
The Impact of Land Use Change on Perform (Soil-Water) System in Middle Part of Mesopotamian Plain
}

\author{
MAJD AL BAYATY ${ }^{1}$, EMAN AL MOUSAWI ${ }^{2 *}$ \\ ${ }^{1}$ University of Babylon, Faculty of Engineering, Department of Civil Engineering, Bakrly 97/60, Babil, Iraq \\ ${ }^{2}$ University of Babylon, Faculty of Engineering, Department of Civil Engineering, Shawy 80/5, Babil, Iraq
}

\begin{abstract}
In spite of hydrology and geology disciplines' are relatively well known in Iraqi management strategy, unlike soil and its distribution system. Thus, describing strong indicator for evaluating water pathways, minerals, and materials in different soils is necessary to reduce the associated risks. However, the aim of this research is identified the change in soil behavior by observation, and interpretation the facts for effective indication mode. This mode is evaluated some features and properties in (soil-water) horizons from a focus on land use change in (e.g built up and rural) areas compared with riparian sites in middle region of Iraq. The evaluation is included field sampling by using "Drill auger" instrument and laboratory tests for analysis. The results areinterpreted as onset of soil impairment indices under changing in human activities, agricultural practices, climate change and effect of water movement. The elements are considerably bound with silt and clay particles which ultimately minimize leaching ability to lower layers in each horizon. The free access of water and air allows rapid oxidation of elements and caused materials corrosion and the output of leaches which can contaminate ground water and surface water. Besides, some elements are negatively correlated with concentrations of calcium carbonate. The content of sulfur compound in assorted land uses is uneven and increased with increase water content or agitating time. Also, the sulfur oxidation even if small proportion in fill material lead to the output of polluted drainage water and attack construction material when structural backfill and for bulk fill. Thus, its significant to consider these features for ameliorative engineering behavior.
\end{abstract}

Keywards: Euphrates river, Riparian region, Land impairment, Mesopotamian plain, Iraq

\section{Introduction}

Soil is at crossway of biosphere, lithosphere, atmosphere, and has a crucial role in all aspects of ecology and human survival. The importance of soil description has been recognized for many decades and endeavor to identify and mapping soils which continually needed [1]. Soil controls water storage and ground water recharge, supports food production, and formed biogeochemical cycles for necessary minerals in the environment [2]. In Iraq, despite of vital case of soil there has been a remarkable shortage in information on (soil - water) system formed major components of urban and rural environments [3]. In this way, soil survey can support to evaluate several aspects of soil characteristics. Assessment soil features and evaluation is relationship with ground water in case to built any structures are needed for urban expanding [4]. Besides include more information about morphological and physical properties such a: porosity, texture, specific gravity, hydraulic conductivity and water content [5]. The impairment of soil is usually begun with bad management and deterioration of vegetation cover. This is led to more compaction, accelerated water erosion, decreased porosity, increase bulk density, and surface crusting, reduction in infiltration rate, and in turn loss of soil fertility [6]. Excess water seepages with tillage may pollute natural soil and with time may cause problems in severalprocess such as: shrinkage, consolidation, soil swelling and reduce the cohesion [7]. In other hand, river banks are substantial transition between aquatic and terrestrial environment [8] and play a essential role in materials cycle of water bodies.

\footnotetext{
*email: majd_albayati@yahoo.com oremanalmusawi33@gmail.com
} 
In addition, the water scarcity in arid and semi-arid regions of the world has encouraged to use untreated wastewater which may contaminate soil environment and thus has toxicological impact on vegetation quality, human health and ground water [9]. Fine soils are conveyed into rivers from watershed by way of surface flow and sub-surface flow [10]. Many studies on effectiveness of land uses about materials inputs into or outputs rivers were carried out at a watershed scale [11,12]. Studies have also attempted to connect the dynamics of riverbank soils with morphological patterns [13], sedimentation [14], hydrologic connectivity [15] and riverbank erosion [16]. The close relation of land use with river water system and aquatic processes requires a better understanding to soils status within a human activity related context [17-19].

Iraq is one of semi arid countries has active human alteration, often pose serious threats of soils which in turn impacted negatively on livelihood, agriculture and infrastructures [20,21]. Hence, evaluation soil status under different land management practices is needed for prospective riverbank management and restoration [20].

However, the target of this research is conduct a survey to evaluate behavior (soil - water) system in various land use categories by observation and interpretation the information. The study will improve the understanding regarding differences in morphological, physical and chemical properties and relation of Calcium carbonate and sulfur compounds with elements detention for surface and subsurface layers conditions of land use change in Mesopotamian plain in Iraq. This assessment can be used to guide lands managers to fill knowledge gaps and establish signs to (soil- water) system degradation for future land management and development projects. Besides, this work will assis to accelerate development of applying GIS to promote integration of soil system and contaminant survey with new techniques.

Soil investigation was performed within a middle region of Iraq belong to Babylon governorate to cover an area of (5315) $\mathrm{km}^{2}$ consisted five major cities and sixteen smaller townships are geographically and administratively united to these major cities (Figure 1). It is attributed to historically as an area located between the Tigris and Euphrates River with wide agricultural and urban sites. The geological formation of study area is characterized as a flat spot with a gentle slope from NW to the SE [22].

Al-Hillah channel is a branch from Euphrates river flowing through Babylon governorate and wide riparian sites around channel were build by flow deposition over centuries. In the past, this channel was accounted as a main course of river, but over time period and as results of continuous processes of erosion and sedimentation of channel had swerved to form another course of Euphrates river with about (15) $\mathrm{km}$ to the West of its ancient course to form Al Hindiyah channel [22]. Al Hillah channel is only and most important resource of water within Babylon governorate where passed within wide areas to supply water for fertile agricultural lands and supply water for civilian uses [23]. The river flows through riparian deposits with elevation ranging between (60) $\mathrm{m}$ asl in the northern part and fall in southern part of governorate to reach (20) $\mathrm{m}$ asl at a rate of slope $(8-12) \mathrm{cm} / \mathrm{km}$ [24].

Babylon Governorate is situated in the Mesopotamians plain which is mainly covered by various types of Quaternary sediments depending on their genesis. The sediment is categorized as fluvial, Aeolian, Lacustrine, polygenic anthropogenic and gypsum soil [22, 24]. The layers of soils were accumulateddue to series of floods. Also, the infiltrate water is only resource for recharging shallow ground water system which impact productivity of agricultural area and affect on building foundations through weak soil stability, reduce bearing capacity, and devastating the paved road [20]. This region is received rainstorms in the winter that usually total of (10-15) $\mathrm{cm}$ per year [25]. The rainfall is not reliable and records a large fluctuation from year to year. The summer is very hot and dry with average temperature of a maximum $(48)^{\circ} \mathrm{C}$. The ground water is varied from region to another and the discharge of Al Hillah channel shown a negative trend, indicating a decrease in mean annual flow because Euphrates regime has shifted towards less pronounced seasonal variation [23] . 


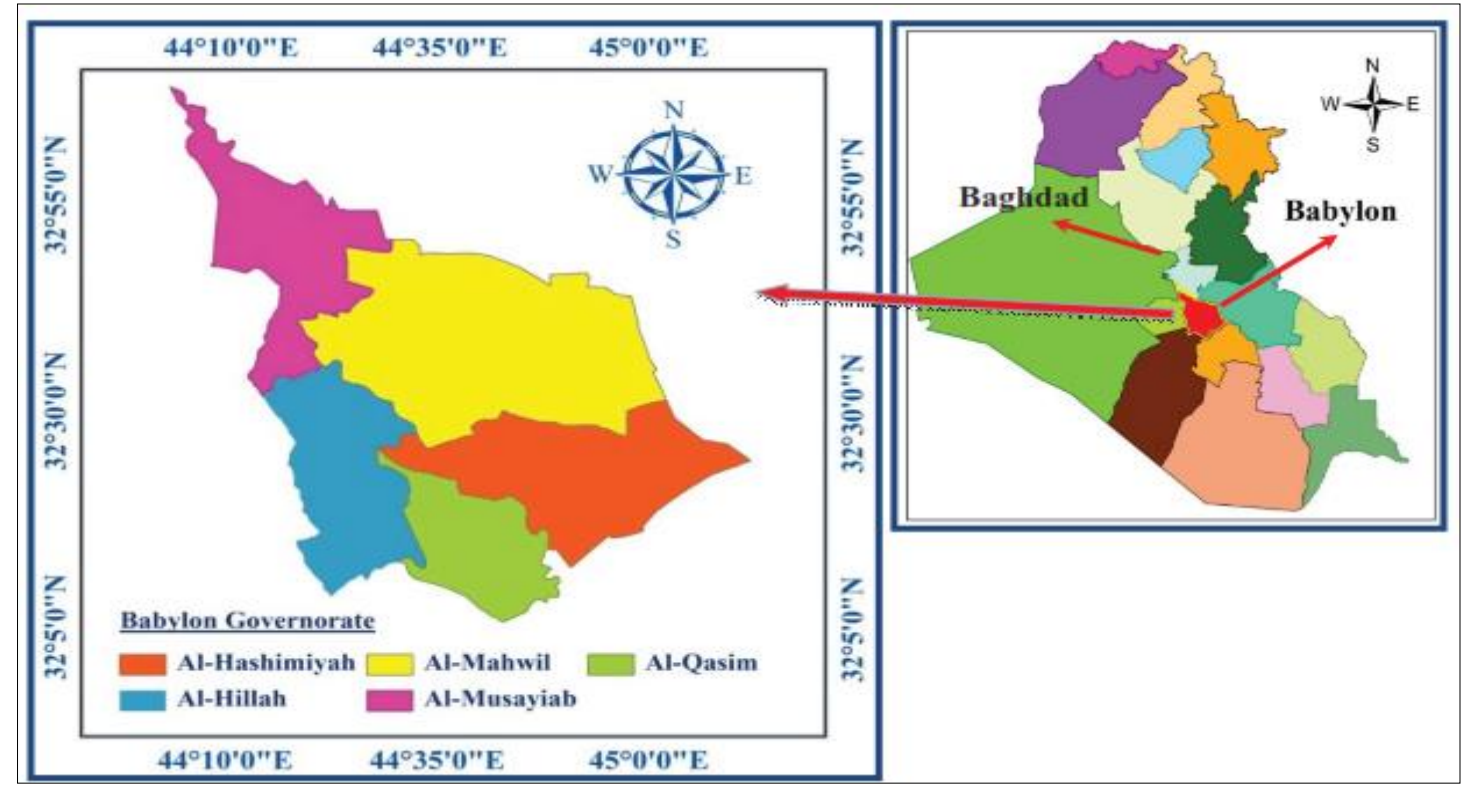

Figure1. Study location map with different land use

\section{Material and methods}

\subsection{Samples collection}

The field survey was conducted on three various land use categories (e.g urban, rural and riparian) to determine the variability in (soil - water) properties across soil stratification. The examination was focused on sites which have significant problems in soil. Therefore, soil profiles were selected randomly across the governorate districts. The sampling was conducted in two boreholes at each category.

A "Drill auger" instrument was used for drilling each boreholes to a depth of (5) m below Natural Ground Surface (N.G.S). Each soil profile was excavation with length and width of $(3 \mathrm{~m} \times 4 \mathrm{~m})$ and all soil horizons were fixed and described. The drilling method was achieved with help of Iraqi Ministry of Housing and Construction authority (National Center for Construction Laboratories and Research Babylon/Iraq) according to [26]. Three soil samples were collected from each layer separated in both middle and corner sides of horizon in each soil profile then samples were mixed for analysis. The type of samples were taken as; Disturbed samples (DS) were collected from the auger cuttings at different depths; Split Spoon Samples (SS) were obtained from a standard split spoon used in the S.P.T (Standard Penetration Test); and Undisturbed Samples (US) were obtained using Shelby tubes depending on stratification of soil. The undisturbed samples were conserved with wax from top and bottom, polyethylene sacks or paraffin and sealed properly at both ends, prevent contamination and also to minimize moisture loss [27]. Then, samples were transported to laboratories for examination and calculation morphological, physical, and chemical properties to each layer.

\subsection{Field Tests}

\subsubsection{Saturated Hydraulic Conductivity (Ks)}

The undisturbed samples are collected for determination a hydraulic conductivity $\mathrm{Ks}\left(\mathrm{cm}^{3} / \mathrm{h}\right)$ depend on [28]. The test is carried out by using freshly cores or in sub-samples from distinct horizons within soil holes. Core samples were gradually wetted until the water level was approximately (4)cm from the bottom of cores. The samples were then allowed to penetrate over a period of time.

\subsubsection{Groundwater Table}

Ground water levels have recorded at end of each boreholes from a natural top surface $(+0.00) \mathrm{m}$ at specified level fixed after $24 \mathrm{~h}$ of bore soils termination, but this level was fluctuated during seasons of the year. 


\subsection{Analysis of Soil Samples}

All samples were transported to the (National Center for Construction Laboratories \& Researches) for examination and analysis. The extracted of elements were somewhat narrow due to limited availability of laboratory resources. In the first phase, samples of disturbed soil are air dried. The main analysis was grain size distribution which achieved in the lab by preparing the core samples and calculated the wet weight. Then dried in an oven at $105^{\circ} \mathrm{C}$ for $24 \mathrm{~h}$ and re -weighed. The dried samples were sieved to $<2 \mathrm{~mm}$ mesh separate coarse fragments. The fine grains were calculated by conventional hydrometer method after dispersion in sodium Hexameter phosphate. Some methods are used for analyzing each samples depend on the type of test and depend on current standards of [27-29] which discussed briefly as below:

2.3.1. Morphological properties: are included horizon type, horizon thickness $(\mathrm{cm})$, matrix color, texture and structure soil consistence, and description of Soil stratification layers depend on terminology of $[27,29]$. The classification of Texture groups according USDA (US Department of Agriculture): Sand $=(\mathrm{S})$, Loamy Sand $=(\mathrm{LS}) ;$ Clayey Sand $=(\mathrm{CS}) ;$ Sandy Loams $=(\mathrm{SL}) ;$ loams $=(\mathrm{L}) ;$ Sandy Clay loam $=$ $(\mathrm{SCL})$; Silty loam $=(\mathrm{SiL})$; Silty Clay loam $=\mathrm{SiCL}$; Clay loam $=(\mathrm{CL})$. Light Clays $=(\mathrm{LC})$; Medium clay $=(\mathrm{MC})$, and Heavy Clay $=(\mathrm{HC})$.

2.3.2. Physical properties: are included: natural values of water content (WC)\%, Specific gravity(Sp) $\%$, and Bulk density (ps) in $\mathrm{g} / \mathrm{cm}^{3}$. The tests were conducted according [27-29].

2.3.3. Chemical properties: are included chemical elements such as Sulfite content as $\left(\mathrm{So}_{3}{ }^{-2}\right)$, Organic Content (ORG) \%;Electrical conductivity (EC) dm/mm; Gypsum $\left(\mathrm{CaSO}_{4}\right) \%$; Calcium carbonate $\left(\mathrm{CaCO}_{3}\right) \%$.The technique of Atomic absorption spectrometry (Spectro Ciros CCD, Germany) after dissolution by (HCL:HNO = 3:1). The solution was filtered and the filtrates were analyzed for the process some elements analysis $(\mathrm{Ca}, \mathrm{Mg}, \mathrm{Mn}, \mathrm{Na}, \mathrm{S}$, and $\mathrm{Zn}$ ) The process of analysis and other properties were performed according methods described by [30, 31].

Principal components analysis were performed using software package XLSTAT for WINDOWS 7 Excel (Microsoft10). The sorted data include the names of the sites and the sites' features, as well as tables containing the data that will use in the analysis process and prepared graphs are represented as mean concentrations of of properties each layer.

\section{Results and discussions}

The describing the soil horizons in situ and average values of tests for different soil layers are discussed as follows:

\subsection{Morphological properties}

The morphological features are regarding the way of accumulation which has a major influence of water on soil behavior, physical properties and how variation with time. The result of tests to all soils layers top surface and down are described in Table 2, while Figure 2 is illustrated photos to each soil profile of select site. The soil texture provides a useful tool for predicting profiles water relations, capacity, erodible and risk of structure decline, and sub-surface compaction. It can be noticed, the layers of soil in built up and rural sites are mostly porous angular blocky and the structure is unstable. The clay content is closely related to the specific area and related soil aeration or drainage system. Color is often used to identify horizon changes down profile. It can also supply an indicator of organic matter content and fertility levels in the soil. As well as redox condition which relates soil aeration (drainage). Therefor, the following is a brief descriptionto feature of each type of soil profile depending on tests values of Table 2. 


\subsubsection{Anthropogenic soil (built up soil)}

The results are represented as this soil is progressively affected by human activity. Most of urban soils are classified as imbalanced soils which consist of material transported from place to place by local public or transported by weathering (e.g wind or runoff rate). Most soils influenced by salinity and scarcity for nutrient. Its oblivious to see clay content is increased with deepest layers, it can be seen various kinds of layers presented in brown color, and deeper layer is dark grey-brown to reddish brown. Change in color is clarify the change in stratification change in the morphological characteristic and presented of minerals ions or iron oxides. A surface soil transformed irreversibly by high temperature and burning into hard cemented (fused) ceramic like porous fragments. These conditions have caused difficulty in leaching salts and action of plant roots. Many medium to hard clay sub-soil has high bulk densities with poor hydraulic conductivity.

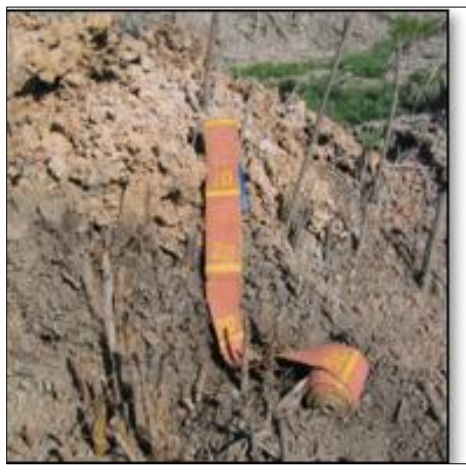

Soil profile 1( Built up soil )

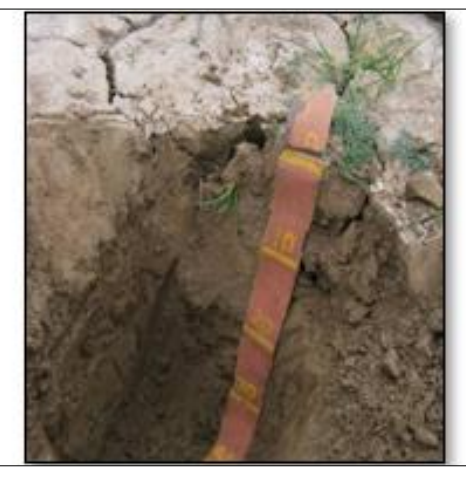

Soil profile 2 ( Riparian soil)

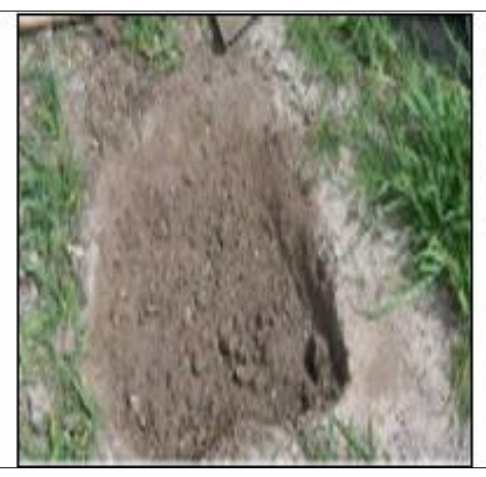

Soil profile 3( Rural soil)

Figure 2. Photos to Soil Horizons for each Land Use Categories

\subsubsection{Riparian Soil}

The original of materials were composited during flood periods by sediment deposition associated with bend sand meanders of channel. The area around Al Hillah channel is an extension of the Iraqi sedimentary plain which sediment composed their layer to represent the bulk of their components. The result of processes that particles of sediment are spread depend on of their sizes. In general, the riparian areas are characterized contain of various portions such as: bends and crescent lakes, which are irregular manifestations besides low swamps have formed due to irregular sedimentation or unevenness of erosion and silting processes. It is recognized that deposition of flood plains and some riparian regions consist of fine sandy material and mixture of silt and clay with some aggregation of coarse particles.

Table 1. The morphological properties of investigation sites

\begin{tabular}{|c|c|c|c|c|c|c|c|c|c|}
\hline \multicolumn{2}{|c|}{ Samples } & \multirow{2}{*}{$\begin{array}{l}\text { Horizon } \\
\text { thickness } \\
(\mathrm{cm})\end{array}$} & \multicolumn{4}{|c|}{$\begin{array}{l}\text { Particle size distribution \& } \\
\text { Hydrometer analysis }\end{array}$} & \multicolumn{3}{|c|}{ Description of Soil layers } \\
\hline $\begin{array}{l}\text { Layer } \\
\text { ID }\end{array}$ & Type & & $\underset{\%}{\text { Clay }}$ & $\begin{array}{c}\text { Silt } \\
\%\end{array}$ & $\begin{array}{c}\text { Sand } \\
\%\end{array}$ & $\underset{\%}{\text { Gravel }}$ & Color & Texture & Structure \\
\hline \multicolumn{10}{|c|}{ Soil profile 1(Built up soil ) } \\
\hline L 1.1 & DS & $0.0-0.5$ & 38 & 37 & 25 & 0 & Brown (10YR 5/3) & CL & Loose \\
\hline L1. 2 & S.S & $0.5-1.0$ & 57 & 16 & 27 & 0 & Dark grey-brown $(2.5 \mathrm{Y} 4 / 2)$ & $\mathrm{MC}$ & Loose \\
\hline L1.3 & US & $1.0-1.5$ & 38 & 40 & 22 & 0 & Brown (10YR 5/3) & CL & Soft \\
\hline L1.4 & S.S & $1.5-2.0$ & 87 & 10 & 3 & 0 & Brown (10YR 5/3) & $\mathrm{HC}$ & Hard \\
\hline L1.5 & US & $2.0-2.5$ & 45 & 43 & 12 & 0 & Brown (10YR 5/3) & $\mathrm{SiC}$ & Friable \\
\hline L1.6 & S.S & $2.5-3.0$ & 69 & 8 & 23 & 0 & $\begin{array}{c}\text { Reddish brown (2.5YR } \\
5 / 6)+ \text { iron oxide }\end{array}$ & $\mathrm{HC}$ & Firm \\
\hline
\end{tabular}




\begin{tabular}{|c|c|c|c|c|c|c|c|c|c|}
\hline L1.7 & US & $3.0-3.5$ & 85 & 9 & 6 & 0 & $\begin{array}{l}\text { Reddish brown (2.5YR } \\
5 / 6) \text { Organic)+iron oxide }\end{array}$ & $\mathrm{HC}$ & Firm \\
\hline L1.8 & S.S & $3.5-4.0$ & 74 & 17 & 9 & 0 & $\begin{array}{l}\text { Reddish brown ( } 2.5 \text { YR } 5 / 6) \\
\text { Irone oxide }\end{array}$ & $\mathrm{HC}$ & Firm \\
\hline L1.9 & S.S & $4.0-5.0$ & 72 & 26 & 2 & 0 & Brown (10YR 5/3) & $\mathrm{HC}$ & Firm \\
\hline \multicolumn{10}{|c|}{ Soil profile 2 (Riparian soil) } \\
\hline L2.1 & DS & $0.0-0.5$ & 12 & 32 & 26 & 30) & Grey $(5 Y$ 6/1) & SiL(gravely) & Loose \\
\hline $\mathrm{L} 2.2$ & S.S & $0.5-1.0$ & 20 & 60 & 20 & 0 & Dark grey-brown(2.5Y 4/2) & $\mathrm{Si} \mathrm{CL}$ & Soft \\
\hline $\mathrm{L} 2.3$ & S.S & $1.0-1.5$ & 17 & 43 & 40 & 0 & Dark grey-brown(2.5Y 4/2) & $\mathrm{L}$ & Soft \\
\hline $\mathrm{L} 2.4$ & S.S & $1.5-2.0$ & 10 & 10 & 80 & 0 & Dark grey-brown(2.5Y 4/2) & SL & Loose \\
\hline $\mathrm{L} 2.5$ & S.S & $2.0-2.5$ & 8 & 10 & 82 & 1 & Greyish -brown $(2.5 Y 5 / 2)$ & SL & Loose \\
\hline L2.6 & S.S & $2.5-3.0$ & 5 & 3 & 91 & 1 & Dark grey-brown(2.5Y 4/2) & SL & Loose \\
\hline L2.7 & US & $3.0-3.5$ & 12 & 56 & 32 & 0 & Olive grey (5Y 5/2) & SiL & Friable \\
\hline $\mathrm{L} 2.8$ & S.S & $3.5-4.0$ & 13 & 33 & 53 & 1 & Very dark grey(2.5Y 3/1) & SL & Friable \\
\hline \multicolumn{10}{|c|}{ Soil profile 3(Rural soil) } \\
\hline L3.1 & DS & $0.0-0.5$ & 32 & 32 & 36 & 0 & Dark grey $(2.5 \mathrm{Y} 4 / 1)$ & $\mathrm{CL}$ & Loose \\
\hline $\mathrm{L} 3.2$ & S.S & $0.5-1.0$ & 38 & 34 & 28 & 0 & Greyish- brown(10YR 5/2) & $\mathrm{CL}$ & Soft \\
\hline L3.3 & US & $1.0-1.5$ & 55 & 24 & 21 & 0 & Greyish-brown(10YR 5/2) & $\mathrm{MC}$ & Soft \\
\hline L3.4 & S.S & $1.5-2.0$ & 33 & 54 & 13 & 0 & Very dark grey(2.5Y 3/1) & $\mathrm{SiCL}$ & Soft \\
\hline $\mathrm{L} 3.5$ & US & $2.0-2.5$ & 55 & 24 & 21 & 0 & Greyish -brown(10YR 5/2) & $\mathrm{MC}$ & Friable \\
\hline L3.6 & S.S & $2.5-3.0$ & 39 & 56 & 5 & 0 & Very dark grey(2.5Y 3/1) & $\mathrm{SiCL}$ & Friable \\
\hline L3.7 & S.S & $3.0-3.5$ & 62 & 26 & 12 & 0 & Greyish -brown(10YR 5/2) & $\mathrm{MC}$ & Firm \\
\hline L3.8 & S.S & $3.5-4.0$ & 48 & 18 & 34 & 0 & Greyish -brown(10YR 5/2) & $\mathrm{C}$ & Firm \\
\hline
\end{tabular}

* Note: $\mathrm{L}_{\mathrm{n}}=$ Identify each category with number of layers were described of: horizon thickness (cm), horizon type [29], and Soil texture is according on USDA classification.

This soil is mostly bare ground but some riversides have covered with vegetation (e.g reeds and trees) in both sides. Generally the soil surface layer has a feature of shrink-swell characteristics when dry. It has ability of adsorbing ions, and disperse when in contact with river water or rainwater. The top layers silt loam to loam have a color grey or dark grey mottles easy cracks, slicken sides. While bottom layers is sandy loam has a dark grey- to brown and olive grey color, mushy, smelly, and permanently wet. In this way highly stratified soil were formed over the old soil and this stratification stretched to the deeper parts from top ground surface. Characteristically, the riparian soil are varied constituent, texture, types, and their quality. The soil bordering river edge is well-drained and changed horizontally through their layers depths from place to another.

\subsubsection{Rural soil (Vegetation soil)}

The formation of this soil was affected by five factors: the land morphology, the climate (e.g temperature, rainfall and wind), living material (e.g vegetation, microbes, fungi, etc.) and sedimentation of irrigation. There is naturally factor associated with activity of rural communities, it's a variation in formation of soil by frequent irrigation with overflowing muddiness which leads to accumulate a thick layer of materials increased with the time. The rural areas are formed a texture as a stratify soil with clay loam or silty clay loam. The soil below $(2.5 \mathrm{~m})$ has represented an ancient soil, and then covered by irrigation deposition over the time. The soil surface is generally covered by vegetation with rich saltand 
nutrients and has plenty of pore space to allow water and air movement and healthy root development. Top layer (s) are throughout uniform in dark grey color and subsurface bottom layer(s) are very dark Grey to Grayish- brown presence some mottles form of organic matter (dark colors) and oxides (brown to red) color and greater resistance. The surfaces layer(s) are drained well because of their features of good drainage properties. Even in wet position (e.g depressions and seepage areas), these soils can subsequently develop to highly saline subsoil horizons. In addition, the consistency test of soils (DS and US) indicated there is some factors have affected consistence such as: mechanical compaction, soil texture, and organic matter content. The soil moisture status has a great influence on the degree of coherence. Soil consistency in a moist section may be classified as a loose, friable, firm or rigid, while in a dry section may be a loose, soft, or hard.

\subsection{Physical properties}

\subsubsection{The property of (water content, specific gravity, bearing capacity and Bulk density)}

A slight difference in values of specific gravity (S.p) among layers of all sites as indicated in Table 2. This difference is due to change in: structure, texture, arrangement of soil particles and compaction. Consequently, this property has an effect on: Hydraulic conductivity and water content. Although of annual tillage, added compost to soil are a main reason of high water content, but the rise in level of ground water and the hydraulic conductivity have other causative. The high water content could cause problems in process of consolidating and soil shrinkage, swelling besides reduce the cohesion [22]. The low water content in riparian sites has resulted from combined the effect of high macro porous and soil structure which led to the rapid drainage [32]. The mean valu is increased with subsurface layers in both built up sites and rural site due texture of soil as mentioned above is (e.g clayey and clayey loam) texture. Also high water content is rise underground level [3]. It is observed a significant difference in values of bulk density of sites soils according horizons layers. The highest bulk density was noticed in built up sites due to corresponding of lower organic matter content, while the lowest values in rural sites. The present of organic matter promotes action of micro and macro organisms which lead to high pore ratio consequently lowering bulk densities [9].

Table 2. The physical properties for investigation sites

\begin{tabular}{|c|c|c|c|c|c|c|c|}
\hline $\begin{array}{l}\text { ID of } \\
\text { layers }\end{array}$ & $\begin{array}{c}\text { Depth } \\
\text { (m) }\end{array}$ & $\begin{array}{c}\text { S p } \\
\%\end{array}$ & $\begin{array}{c}\text { WC } \\
\%\end{array}$ & $\begin{array}{c}\text { Bulk density } \\
\text { (ps) } \\
\left(\mathrm{g} / \mathrm{cm}^{3}\right)\end{array}$ & $\begin{array}{c}\text { Hydru. } \\
\text { Conductivity } \\
\text { Ks } \\
(\mathbf{c m} / \mathbf{h r})\end{array}$ & $\begin{array}{c}\text { Allawa. bearing } \\
\text { Capacity } \\
\left(\mathbf{t} / \mathbf{m}^{2}\right)\end{array}$ & $\begin{array}{l}\text { Water table } \\
\text { Below N.S } \\
\quad(\mathbf{m})\end{array}$ \\
\hline \multicolumn{8}{|c|}{ Soil profile (Built up area) } \\
\hline L1.1 & $0.0-0.5$ & 2.72 & 26.14 & 1.573 & 27.73 & 8 & \multirow{3}{*}{2.0} \\
\hline L1.2 & $0.5-1.0$ & 2.73 & 31.04 & 1.450 & 20.47 & 12 & \\
\hline L1.3 & $1.0-1.5$ & 2.76 & 30.42 & 1.423 & 21.68 & 11 & \\
\hline \multicolumn{8}{|c|}{ Soil profile (Riparian area) } \\
\hline L2.1 & $0.0-0.5$ & 2.68 & $15 . .08$ & 1.321 & 17.04 & 12 & \multirow{4}{*}{3.2} \\
\hline L2.2 & $0.5-1.0$ & 2.68 & 18.34 & 1.215 & 15.12 & 7 & \\
\hline L2.3 & $1.0-1.5$ & 2.68 & 28.94 & 0.870 & 15.47 & 6 & \\
\hline L2.4 & $1.5-2.0$ & 2.64 & 20.46 & 0.850 & & & \\
\hline \multicolumn{8}{|c|}{ Soil profile (Rural area) } \\
\hline L3.1 & $0.0-1.0$ & 2.71 & 32.24 & 1.203 & 25.93 & 7 & \multirow{4}{*}{2.7} \\
\hline L3.2 & $0.5-1.0$ & 2.71 & 29.56 & 1.12 & 25.68 & 8 & \\
\hline L3.3 & $1.0-1.5$ & 2.73 & 30.34 & 0.73 & 21.79 & 10 & \\
\hline L3.4 & $1.5-2.0$ & 2.73 & 39.72 & 1.047 & 35.83 & 14 & \\
\hline
\end{tabular}


Also, the prevailing public practices (e.g hoeing lands and removal of organic matter via construction sites) which contributed to decrease levels of organic matter [16]. Thus, the disturbance due to extension in urban areas combined with low organic matter might result to high bulk densities. The bulk density of soil samples in farms showed a relatively constant value across soil horizons. In other hand, the main variation in each layer is attributed to variation in content of parent materials (e.g dolomite rocks and limestone) besides alteration in agricultural practices. In overall, its revealed that degradation in horizons layers are decreased further away from pollution source (e.g industries sites) like characteristics of riparian soil [32].

\subsubsection{The Saturation Hydraulic conductivity (ks)}

It's clear from Table 2 that high value of (Ks) to surface layer(s) compared with subsurface layers in all land uses categories in view of fact of no compaction The silty loamy texture is created a high space of macros pores responsible of water movement and if macro pores are reduced, the KS becomes low to confirm the fact that pore space and texture are correlated significantly with KS beside effect some elements ions to reduce percolation. In general, disturbance of removing soil in built up sites compared riparian sites due to fact of continuous removal of top soil for construction activities could give a rise in soil impairment and reduce their saturated Hydraulic conductivity [15]. While action of trees roots and periodic addition of organic materialsfor improvement rural soil accountable for increase KS. Very high concentrations of fine calcium carbonate $\left(\mathrm{CaCO}_{3}\right)$ could reduce $\mathrm{KS}$ and provide crust formation is prevent water permeation and restriction root growth [19]. Also, its realized that differences in bulk density always changes hydraulic conductivity and high bulk densities is lowering Ks.

\subsection{Chemical Tests}

The examination of chemical tests were conducted for all soil layers and results values of each land use category are represented in Table 3 and Figure 3 as a mean value for each layer. Traditionally, sulfate has been denoted as $\mathrm{SO}_{3}$, although the correct form is $\mathrm{So}_{4}$. The $\mathrm{SO}_{3}$ is a gas does not exist in nature, while the sulfite ions $\mathrm{SO}_{3}{ }^{-2}$ only occur in water and related analysis of rocks and soil in terms of oxides and their ability to attack concrete and foundation materials thus, its expressed in limiting values as term of sulfite $\mathrm{SO}_{3}$ with percentage value. The highest content of $\mathrm{SO}_{3}$ in riparian soils is greater than (1)\% to be sorted as unacceptable risk according to level of risk associated due to nature of weathering, duration of transport sediments and $p \mathrm{H}$ value variation. While rural areas recorded below $(0.3) \%$ at low risk level. Some areas covered with white color is classified of 'Saline- or Alkali 'soil to reflect the arid and semi arid zone of Iraq. Also, some of drying or burning of residues materials may decrease soil organic matter accumulation and impacted on physical condition. In this case, organic matter of soil samples is varied in built up, riparian and rural sites respectively at surface layer (L1.1, L2.1, L 3.1) and these values are decreased moderately far away from soil surface in both built up and rural sites and increased in riparian sites. The organic matter may promote some elements oxidation in soil because clay is negatively charged but this does not likely react with Pyrite $\left(\mathrm{FeS}_{2}\right)$ or releasing sulfur dioxide gas. In rural site, formation of soil structure, texture, roots presence, were all more dominant in the surface soil as compared to lower layers of soil horizon [6]. Added livestock manures can recover the organization of mineral ions in sub-soils and promote soil aggregation through clay minerals compound [5]. Whereas built up soils is rich in clay but deficient in organic materials may form a soil of heavy fragments almost impenetrable to water or plant roots its influenced by salinity and sodicity. While more addition of salts and minerals from domestic and industrial wastes in the surface soil layers than the deep soil horizons [22]. The results of most soil profiles are contained a high percentage of $\mathrm{CaCo}_{3}$. These values exceeded dramatically with underground layers to reach maximum values in all study sites at a layer depths (L 1.5 , L 2.5, L $3.5 \mathrm{~m}$ ). This is due to the effect of geological pattern of Mesopotamian plain which contain high quantities of limestone rocks. The application of numerous bio-solids (e.g chemical fertilizer, pesticides, and atmospheric deposition. etc) to the land may lead to more accumulation calcium carbonate $\mathrm{CaCO}_{3}$ [20]. Moreover, the arid climate which are contributed to a rise of carbon compounds 
from groundwater to the surface [31]. In general, the exceeded of $\mathrm{CaCo}_{3}$ content could slow down elements movement and rise chance of bindings Figure 3. In sub surface layers may cause soil impairment and led more engineering problems such as: differential in buildings foundations because weak in bearing capacity, cracks and failure [16]. The informal agricultural processes and poor drainage besides human action by dumping untreated sewage led to excess salinity and pollution soil [17]. In other factors like: land characteristics (e.g geology and parent rock), the sharp climatic variations (e.g temperature, high rate of evaporation, and salts accumulation) increase exchange of elements ions [10]. Naturall, the fate and transport elements in soil is depended crucially on the action of each element and its composition in the soil besides its interaction with water [19].

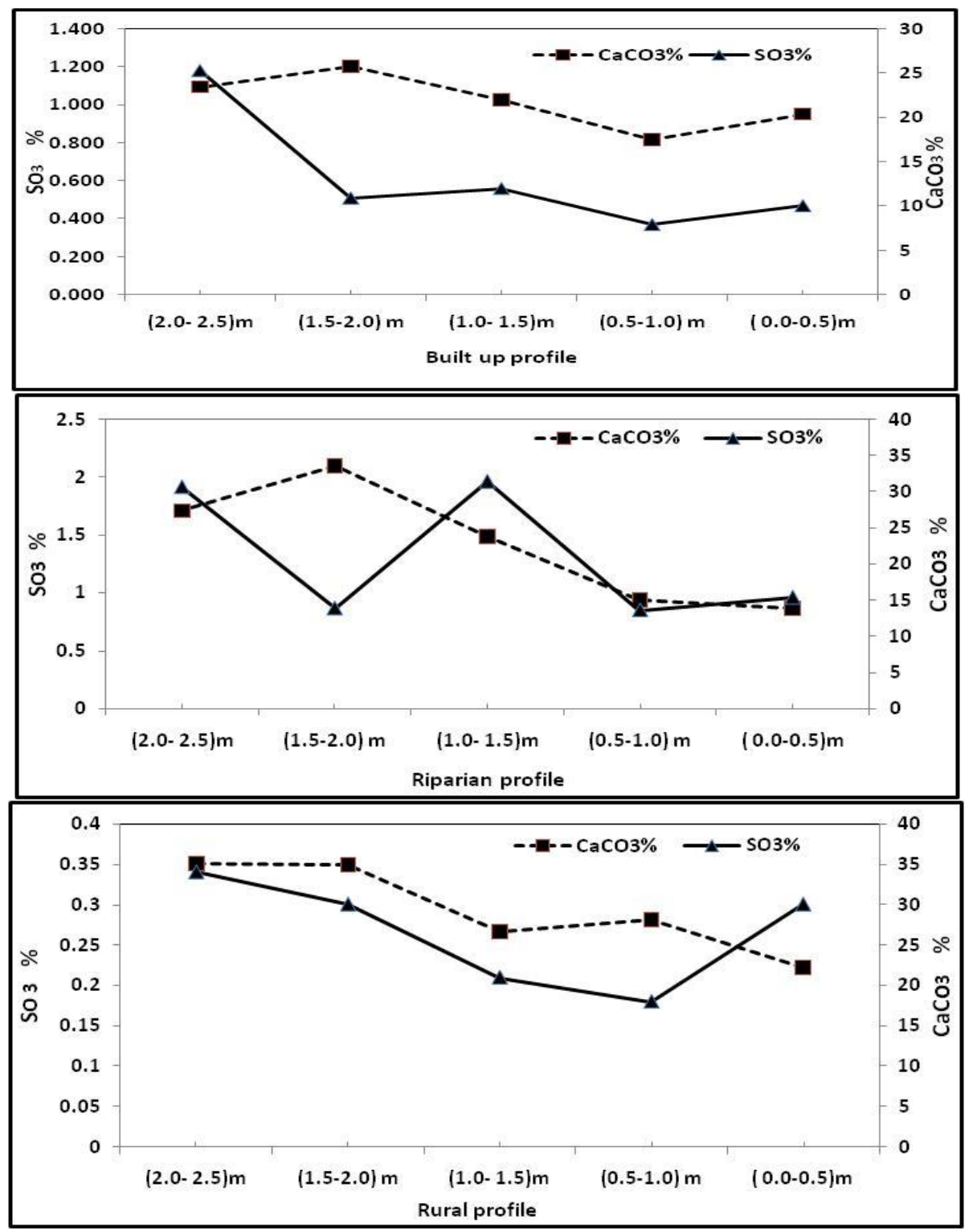

Figure 3. The variation in percentage of $\left(\mathrm{CaCO}_{3}\right)$ and $\left(\mathrm{SO}_{3}\right)$ content in different land use horizons and different layers

In addition, results are demonstrated that salts and minerals are seasonally products and increased with high temperature and excess movement of water such in irrigation purpose or heavy rain. It could be caused increase in soil contamination. Most of salts crusts are resulted from evaporation of saline waterduring irrigation and minerals transfer with water percolation to associate with ground water [6. 
In other hand, most of soils are progressively affected by element ions retransformed from ground water by 'Osmotic water' which aggravated stress and impacted on water consumption [11]. The salts concentration in ground water have effective influenced on soil system. The sediment in riparian sites may effect on many chemical reactions where containing acidic minerals which released with large amounts into ecosystem [18]. Soil materialism in their pristine state may cause potential saline occurred and buried beneath alluvium layer. It caused by geochemistry of sediment where originally came from sedimentary rocks transported by Euphrates river [2].

Otherwise, the interaction of $\mathrm{Cl}, \mathrm{Na}, \mathrm{Ca}, \mathrm{Mn}$ and $\mathrm{Mg}$ with water have specific effects in each layer depth. The concentration of $\mathrm{Cl}$ and $\mathrm{Na}$ is showed a slightly increment further away from the top surface, while concentration follows no definite pattern with increasing distance in other elements. The values in Table 3 are illustrated that distribution of elements are unsteady across layer depths for all land use sites. These concentrations are increased gradually with layer(s) depth because salt is leaching with infiltration water. The $\mathrm{Mg}$ is as well found has serious effect on both infiltration rate and erosion when the soil is exposed to rainfall. The extractable $\mathrm{Mg}$ may promote dissolution of $\mathrm{CaCo}_{3}$ and rise the electrolyte concentration in the soil solution, thus preventing clay dispersion and a decrease in permeability of soils [31]. In other hand, the influence of elements on soils is obvious especially the free space between anthropogenic sites, when land has completely dried out byeffect of an arid climates and burn soil materials in high temperature of summer season. This state resulted a rise in concentration of Na when exchangeable disperses with organic matter and causes clay particles deflocculates [16]. In built up area, the top soil is transformed irreversibly into hard cemented (fused) ceramic-like porous fragments.

Table 3. The chemical Properties for Investigation Sites

\begin{tabular}{|c|c|c|c|c|c|c|c|c|c|c|c|c|}
\hline \multirow{2}{*}{$\begin{array}{l}\text { Lay- } \\
\text { ers ID }\end{array}$} & \multirow{2}{*}{$\begin{array}{l}\text { Horizon's } \\
\text { thickness } \\
\text { (m) }\end{array}$} & \multirow{2}{*}{$\begin{array}{l}\text { EC } \\
(\mathrm{d} s / \mathrm{m})\end{array}$} & \multirow{2}{*}{$\begin{array}{l}\text { ORG. } \\
\%\end{array}$} & \multirow{2}{*}{$\begin{array}{l}\text { Gypsum } \\
\text { (CaSO4) } \\
\%\end{array}$} & \multicolumn{7}{|c|}{ Concentration of major Elements ( $\mathrm{mg} / \mathrm{kg})$} & \multirow{2}{*}{$\begin{array}{l}\text { Sulfite } \\
\text { inW.T } \\
(\mathrm{mg} / \mathrm{l})\end{array}$} \\
\hline & & & & & $\begin{array}{l}\mathrm{CL} \\
(\mathrm{mg} / \mathrm{kg})\end{array}$ & $\begin{array}{l}\mathrm{Na} \\
(\mathrm{mg} / \mathrm{kg})\end{array}$ & $\begin{array}{l}\mathrm{Mn} \\
(\mathrm{mg} / \mathrm{kg})\end{array}$ & $\begin{array}{l}\mathrm{Zn} \\
(\mathrm{mg} / \mathrm{kg})\end{array}$ & $\begin{array}{l}\mathrm{S} \\
(\mathrm{mg} / \mathrm{kg})\end{array}$ & $\begin{array}{l}\mathrm{Ca} \\
(\mathrm{mg} / \mathrm{kg})\end{array}$ & $\begin{array}{l}\mathrm{Mg} \\
(\mathrm{mg} / \mathrm{kg})\end{array}$ & \\
\hline \multicolumn{13}{|c|}{ Soil profile (Built up area) } \\
\hline L 1.1 & $0.0-0.5$ & 3 & 0.18 & 2.928 & 1400 & 1500 & 522 & 79 & 2100 & 9000 & 13000 & \multirow{5}{*}{289.0} \\
\hline Ll. 2 & $0.5-1.0$ & 5.2 & 0.27 & 3.862 & 1780 & 1100 & 315 & 81 & 3200 & 12000 & 11000 & \\
\hline L1.3 & $1.0-1.5$ & 14.9 & 0.13 & 1.75 & 2985 & 2700 & 300 & 72 & 2300 & 17000 & 16000 & \\
\hline L1.4 & $1.5-2.0$ & 11 & 0.12 & 1.828 & 3235 & 1800 & 473 & 50 & 3200 & 9000 & 10000 & \\
\hline $\bar{L} 1.5$ & $2.0-2.5$ & 7.9 & 0.16 & 1.22 & 2114 & 2200 & 550 & 56 & 5200 & 15000 & 13000 & \\
\hline \multicolumn{13}{|c|}{ Soil profile (Riparian area) } \\
\hline L 2.1 & $0.0-0.5$ & 4.9 & 0.70 & 3.74 & 2150 & 800 & 466 & 61 & 5700 & 9970 & 7000 & \multirow{5}{*}{97.4} \\
\hline L2.2 & $0.5-1.0$ & 5.6 & 1.35 & 0.94 & 2223 & 1200 & 445 & 59 & 5000 & 9895 & 9000 & \\
\hline L2.3 & $1.0-1.5$ & 4.3 & 1.07 & 1.19 & 1123 & 1300 & 500 & 55 & 1250 & 8000 & 6000 & \\
\hline L2.4 & $1.5-2.0$ & 5.4 & 1.50 & 0.12 & 1868 & 700 & 440 & 57 & 1350 & 8006 & 9000 & \\
\hline L 25 & $2.0-2.5$ & 7.7 & 1.10 & 0.08 & 2672 & 200 & 390 & 38 & 1050 & 3450 & 10000 & \\
\hline \multicolumn{13}{|c|}{ Soil profile (Rural area) } \\
\hline L3.1 & $0.0-0.5$ & 3.9 & 6.20 & 0.73 & 1003 & 900 & 386 & 64 & 5300 & 9000 & 8000 & \multirow{5}{*}{168.3} \\
\hline L3.2 & $0.5-1.0$ & 4.5 & 4.30 & 0.64 & 947 & 1400 & 377 & 72 & 5000 & 7015 & 8000 & \\
\hline L3.3 & $1.0-1.5$ & 5.7 & 3.60 & 0.45 & 1232 & 1200 & 380 & 61 & 8000 & 7500 & 11000 & \\
\hline L3.4 & $1.5-2.0$ & 6.6 & 13.8 & 0.39 & 2047 & 1400 & 372 & 46 & 6000 & 8090 & 11000 & \\
\hline $\mathrm{L} 3.5$ & $2.0-2.5$ & 7.8 & 6.7 & 0.64 & 2327 & 1700 & 366 & 40 & 5000 & 4000 & 13000 & \\
\hline
\end{tabular}

This production caused a decrease in infiltration rate, unstable soil, aggregations, and increase in runoff rate although the exchange complex may composed of divalent elements such as $\mathrm{Ca}$ and $\mathrm{Mg}$. Likewise, the Sulfur (S) has diffused in bottom layers (L1.4, L2.4, and L3.4) and (L1.5, L2.5, L3.5) but 
if be into soil surface it may react with the oxygen in the air. In turn the acid either reacts with carbonates and clay minerals in soils and sediments or drains into waterways to form sulphate form liberating dissolved other elements [31]. The water soluble sulfur compounds attack construction material when used in structural backfill or bulk fill. As well results are shown $\mathrm{Zn}$ concentration is raised unnaturally. The anthropogenic addition, industrial sources or toxic waste sites may cause excess of Zn concentration in soil and rivers water. A consequence is that Zn-polluted sludge and Water-soluble zinc that is located in soils can contaminate groundwater [30].

\section{Conclusions}

The comparative soil survey has identified a potential impairment in local soils which may consequently lead to a large future risk impacted lands and water resources. A clear and contrasting patterns of changing in soil characteristics with depth formation in each land use category. The effect of human activities is negatively on properties of built up soils through causing permanent variation in formation of soils. The wastes dumps, drainage and tailings, irreversibly fused created new types of particulate and discrete artifacts fragments over a vast area. Other factors are played main roles in degradation soils such as: parent materials, weathering, corrosion, sulfur oxidation, $\mathrm{CaCO}_{3}$ and movement dissolute elements ions in water through soil profile. Besides, the rise of ground water has a great influence on degree of coherence in built up and rural regions by transformation soil to state of: shrinkage, consolidation, soil swelling besides reduce the cohesion and led to rise salts in soil profile. Patterns of elements are most likely associated with materials inputs to the soil with water. Regarding riparian soils, there is a significant role for aggregation sediment in some place and erosion in another besides moving materials with elements through and out of aquatic system. As well as movement and accumulationof elements may caused by the effect of geochemistry of sedimentary rocks transported by Euphrates river. Sulfur compounds oxidation of even of small proportion present in fill material can lead to the production of polluted drainage water which requires treatment prior to discharge to watercourse. This is in addition to attack on construction material.

Acknowledgments.The research has been supported financially by authors themselves, but they would like to thank the staff of (National Center for Construction Laboratories and Research, Babylon/Iraq) for the help.

\section{References}

1.BUEKERS, J., Fixation of Cadmium, Copper, Nickel and Zinc in Soil: Kinetics, Mechanisms and its Effect on Elements availability, Ph.D. hesis, Katholieke University Lueven, De Agriculture, 2007.

2.MEDZINI, A., WOLF, A.T., The Euphrates River Watershed: Integration, Coordination or Separation in Multi-Governance of Water: Four Case Studies. New York, 2005.

3.SMITH, D. B., CANNON, W.F., WOODRUFF, L. G., SOLAN, O.F., KILBURN, J. E., Geochemical and Mineralogical Data for Soils of the Conterminous. United States U.S. Geological Survey Data Series, 8(10), 2002.

4.***ICRAF, Nairobi. The Influence of Mechanical Clearing of Forest on Some Physical and Chemical Properties, Surinamese Land bouw, 2003, 2-14.

5.BIGHAM, J. M., FITZPATRICK, R. W., SCHULZE, D. G., Soil Mineralogy with Environmental Applications. Soil Science Society America Book Series No 7. SSSA, Wisconsin British Standards, 2002,199- 234.

6.PIERZYNSKI, G.M., SIMS, J.T., VANCE, G.F., Trace Elements: Soils and Environmental Quality, 1 Ed, Taylor and Francis Group, London, 2005, 331-36.

7.EKHOL, M. P., LEHTORANT, A. J., Does Control of Soil Erosion Inhibit Aquatic Eutrophication Environ, 93 (140), 2012, 6-144, 
8.BARTELS, P., CUCHEROUSSET, J., STEGER, K., EKLÖV, P., TRANVIK, L.J., HILLEBRAND, H., Reciprocal Subsidies between Freshwater and Terrestrial Ecosystems Structure Consumer Resource Dynamics Ecology, 93, 2012, 1173-82,

9.KHAN M, SCULLION J., Effect of Elements Enrichment of Sewagesludge on Soil Micro organics and their activities. Appl. Soil Ecol., 20, 2002, 145-155.

10.KLAUS, V.H., SINTERMANN, J., KLEINEBECKER, T., HÖLZEL, N., Sedimentation-Induced Eutrophication in Large River Floodplains. An Obstacle to Restoration Conserve, 144, 2011,8 -451.

11.BIGHAM, J. M., FITZPATRICK, R. W., SCHULZE, D. G., DIXON, J.B., SCHULZE, D.G., Soil Mineralogy with Environmental Applications. Soil Science Society America Book Series, 2002.

12.LIU, X., VIDON, P., JACINTHE, P. A., FISHER, K., BAKER, M., Seasonal and Geomorphic Controls on N and P Removal in Riparian Zones of the US Biogeochemistry, 119, 2014 ,245-57.

13.TUFEKCIOGL, U. M., ISENHART, T.M, SCHULTZ, R. C., BEAR, D.A., KOVAR, J. L. RUSSELL, J. R., Stream bank Erosion as a Source of Sediment and Phosphorus in Grazed Pastures of the Rathbun Lake Watershed in southern Iowa, United States US Soil, Water Conserve, 67, 2012, 54555

14.IGLESIAS, M. L., DEVES, A. R., PÉREZ - MOREIR, A. R., DÍAZ-FIERROS, F., BARRAL, M. T., Phosphorus Transfer across Boundaries: From Basin Soils to River bed Sediments, Soil Sediment, 11, 2011, 34-1125

15.WOLF, K.L., NOE, G. B., AHN, C. A, Hydrologic Connectivity to Streams increases Nitrogen and Phosphorus inputs and Cycling in Soils of created and Natural Floodplain wetlands, 42, 2013, 1245-55. 16.LEVY, D. B., BARBARICK, K. A., SIEMER, E. G., SOMMERS, L.E., Distribution and Partitioning of Trace Elementss in Contaminated Soils near Leadville, Colorado, Journal of Environmental Quality, 21(2), 1992, 185-195.

17.ZHAO, Q., KALUARACHCHI, J. J., Risk Assessment at Hazardous Waste Contaminated Sites with Variability of Population Characteristics, Environment International, 28(12), 2002, 41-53,

18.ARSHAD, M. A., COEN, G. M., Characterization of Soil Quality: Physical and Chemical Criteria. America Journal Alternative Agriculture, 7, 1992, 25-31.

19.FITZPATRICK, R. W., MERRY, R. H., COX, J.W., RENGASAMY, P., DAVIES, P.J., Assessment of Physico-chemical Changes in Dry land Saline Soils When drained or Disturbed for Developing Management Options. CSIRO, Land and Water Technical Report 02/03. CSIRO, 56, 2003 b.

20.YASIN, M., Some Geotechnical Properties of soil in Haditha Area, Iraq, Inter Association of Eng. Geology, 41, 1990, 7-10

21.***FAO. Irrigation in the Middle East Region in of Aqua Stat Survey, In FAO Reports 34, Rome, 2009.

22.KHALAF, M. O., Study the Physical Properties of Al Hamzah City Soil Babil Province, First University of Babylon Magazine, 1(18), 2010.

23.*** MWR, Ministry of Water Resources-Iraq, Schematic Diagram of Main Control Structures in Iraq, General Directorate of Water Resources Management, Hydrological Studies, 2019.

24.JASSIM, S. Z., GOF, J.C., Geology of Iraq. Published by Dolin, Prague and Moravian Museum, 2006, p. 1

25.***IMP, Iraqi Ministry of Planning. Records of Directorate of Census Babylon. Internal reports. Baghdad: Iraqi Ministry of Planning, 2015.

26.***IMHC, Iraqi Ministry of Housing \& Construction, National Center for Construction Laboratories and Research Babylon-Iraq, 2019.

27.***ASTM-D 854-92, (American Society for Testing and Material), FM 5-472/Navfac Mo 330/Afjman (I)., 2010, 32-1221.

28.SCHOENEBERGER, P.J., WYSOCKI, D.A., BENHAM, E. C., BRODERSON, W. D., Field Book for Describing and Sampling Soils, Version 2.0. Natural Resources Conservation National Soil Survey Center, Lincoln, USA, 2002. 
29.***Soil Survey Staff, Soil soil taxonomy. Abiasic system of soil classification for making and interpret soil survey. In: Agricultural handbook No436, $2^{\text {nd }}$ USDA- NRCSPP.869, 1999.

30.***APHA (American Public Health Association), Standard Methods for Examination of Water and Wastewater, 20 th Ed. Washington DC, USA, 2003.

31.PARSONS, T. R., MAI, T.Y., LAULLI, C. M, A Manual of Chemical and Biological Methods for Seawater Analysis, Pergamone Press Oxford, 1984.

32.RUMPE, L.C., ALEXI, S. M., CHABB, I. A., CHAPLO, T. V., RASSE, D.P., VALENTI, N.C., MARIOTT, I.A., Black Carbon Contribution to Soil Organic Matter Composition in Tropical Sloping Land under Slash and Burn Agriculture Gendarme, 130, 2006, 35-46

Manuscript received: 31.08 .2020 